\title{
ANALISIS PUTUSAN HAKIM PENGADILAN NEGERI KARANGANYAR DALAM MEMUTUS PERKARA PIDANA HAK CIPTA GUNA MENCIPTAKAN KEPASTIAN HUKUM CIPTA (Putusan Perkara No.172/Pid.B/2011/PN.Kray.)
}

\author{
Riyan Aditya Nugraha \\ riyannugraha573@gmail.com \\ (Mahasiswa Program Magister Hukum FH UNS) \\ Widodo Tresno Novianto \\ novianto@consultant.com \\ Supanto \\ supanto8787@gmail.com \\ (Dosen Fakultas Hukum UNS)
}

\begin{abstract}
This article aims to determine the Decision of the District Court of Karanganyar in deciding the case No.172 / Pid.B / 2011 / PN.Kray in case of Copyright between PT. Sri Rejeki Isman with PT. Delta Merlin The Texstile world has created legal certainty Is a Normative study Types of data use Secondary data, data source using Secondary Data Source which includes Primary Law Material, Secondary Law Material and Tertiary Law Material. Methods of data collection through Library Studies. Data analysis using deductive logic analysis method with qualitative approach. Research shows that the Decision imposed by the Karanganya District Court judge No.172 / Pid.B / 2011 / PN.Kray in case of Copyright between PT. Sri Rejeki Isman with PT. Delta Merlin World Texstile provides legal certainty for the parties to the dispute. The judge decided by considering the evidence and witnesses during the trial. The verdict handed down by law is fixed.
\end{abstract}

Keywords: Copyright; Judge’s Verdict; Legal Certainty

\begin{abstract}
Abstrak
Artikel ini bertujuan untuk mengetahui Putusan Hakim Pengadilan Negeri Karanganyar dalam memutus perkara No.172/Pid.B/2011/PN.Kray dalam kasus Hak Cipta antara PT. Sri Rejeki Isman dengan PT. Delta Merlin Dunia Texstile sudah menciptakan kepastian hukum Merupakan penelitian Normatif Jenis data menggunakan Data sekunder, sumber data menggunakan Sumber Data Sekunder yang meliputi Bahan Hukum Primer, Bahan Hukum Sekunder dan Bahan Hukum Tersier. Metode pengumpulan data melalui Studi Pustaka. Analisis data menggunakan metode analisa logika deduktif dengan pendekatan kualitatif. Penelitian menunjukkan bahwa Putusan yang dijatuhkan oleh hakim pengadilan negeri Karanganya No.172/Pid.B/2011/PN.Kray dalam kasus Hak Cipta antara PT. Sri Rejeki Isman dengan PT. Delta Merlin Dunia Texstile memberikan kepastian hukum bagi para pihak yang bersengketa. Hakim memutus dengan mempert5imbangkan barang bukti dan saksi selama dalam persidangan. Putusan yang dijatuhkan berkekutan hukum tetap.
\end{abstract}

Kata Kunci: Hak Cipta; Putusan Hakim; Kepastian Hukum. 


\section{A. Pendahuluan}

Hak Kekayaan Intelektual (HKI) yang merupakan terjemahan dari Intellectual Property Rights sebenarnya adalah keberadaan hak-hak yang lahir atas perwujudan kreasi intelektual manusia yang mencakup rasa, karsa, dan cipta manusia. Berdasarkan konvensi internasional yang menjadi induknya, maka HKI dikategorikan dalam dua lingkup besar, yakni Hak Cipta dan Hak-hak yang berkenaan dengan Hak Cipta (Copyright and Related Right) yang berdasar pada Konvensi Berne (Berne Convention 1886) tentang Protection for Literary and Artistic Works, dan Hak Kekayaan Industrial (Industrial Property) yang berdasar pada Konvensi Paris (Paris Convention 1883) yang melindungi hak-hak industrial meliputi Paten, Merek, Desain Industri, Rahasia Dagang, Topography Sirkuit Listrik Terpadu dan sebagainya.

Hukum Hak Cipta dalam perspektif intenasional, selain telah diadopsinya Konvensi Berne (Berne Convention for the Protection of Literary and Artistic Works), dalam perjalannya selalu mengalami perkembangan. Sebagai bukti dari perkembangan tersebut pada tahun 1971 ketika dikeluarkan sebuah konvensi internasional yang mengatur HKI, yaitu; Geneva Convention for the Protection of Producers of Phonograms againts Unauthorisec Duolication of their Phonograms. Lebih dari 40 negara mengadopsi konvensi ini.

Selanjutnya bulan Desember 1996 WIPO (World Intellectual Property Organization) mengundang 160 negara untuk membahas modifikasi norma konvensional dan menjadikannya norma baru yang mengatur masalah HKI. Lingkup yang diusulkan untuk dimodifikasi yakni kreasi, adopsi, transmisi dan distribusi karya melalui medium digital. Pada akhirnya, Copright Treaty dan Performance and Phonograms Treaty diadopsi oleh negara-negara peserta konfrensi. Dengan diadopsinya Copright Treaty (WIPO Copright Treaty), maka untuk computer software and computer program dalam segala bentuk dan modelnya dilindungi oleh karya literari (Literary work) dan timbul hak baru yang disebut hak transmisi (right of transmission), yang hal ini menambahkan dari hak sebelumnya yang terdiri dari; hak reproduksi, hak public performance dan komunikasi.

Sejak ditandatanganinya Agreement Establishing The World Trade Organization (WTO) beserta lampiran-lampirannya, perlindungan HKI secara internasional semakin ketat. Oleh karena itu, negara-negara yang turut serta dalam kesepakatan internasional, yang dalam kerangka GATT/WTO (1994), yaitu kesepakatan TRIPs (Agreement On Trade Related Aspects Of Intellectual Property Rights) sebagai salah satu hasil dari Final Act Embodying The Uruguay Round Of Multilateral Trade Negotiation harus menyesuaikan peraturan nasionalnya dengan kesepakatan TRIPs. Indonesia termasuk salah satu negara yang ikut menandatangani kesepakatan itu dan meratifikasinya dengan Undang-Undang Nomor 7 Tahun 1994 tentang Ratifikasi Perjanjian Pembentukan Organisasi Perdagangan Dunia.

Negara-negara Eropa Barat menjadi peserta Konvensi Berne, mendorong negara Belanda memperbaharui undang-undang hak ciptanya yang sudah berlaku sejak 1881, pada tanggal 1 November 1912. Tidak lama setelah Auterswet 1912 diundangkan, Belanda mengikatkan diri pada Konvensi Berne 1886, pada tanggal 1 April 1913 dengan beberapa reservation. Hindia Belanda sebagai daerah jajahan Belanda diikutsertakan pada konvensi ini sebagaimana diumumkan dalam Staadblad 1914 Nomor 797. (Hendra Tanu Atmadja, 2003:40)

Auterswet 1912 terus berlaku setelah Proklamasi Kemerdekaan Indonesia berdasarkan Pasal II Aturan Peralihan, Undang-undang Dasar 1945 dan Peraturan Presiden No.2 tanggal 
10 Oktober 1945, sampai dengan diundangkannya UU No.6 Tahun 1982 tentang Hak Cipta. Meskipun saat itu Indonesia telah memiliki aturan yang mengatur hak cipta, tetapi masalah hak cipta tidak populer. Bahkan pada tahun 1958 Indonesia sempat keluar dari keanggotaan Konvensi Berne. Baru pada tahun 1965 Indonesia kembali melakukan upaya-upaya untuk menyusun undang-undang hak cipta yang kemudian lahir UU No.6 Tahun 1982 tentang Hak Cipta. Lima tahun kemudian UU No.6 Tahun 1982 diperbaharui dengan UU No.7 Tahun 1987.

Sejalan dengan keikutsertaan Indonesia dalam perjanjian multilateral GATT/WTO, di mana di dalamnya tercantum Agreement on Trade Related Aspect of Intellectual Property Right (TRIPs), maka konsekuensi yuridis yang harus dilakukan adalah Indonesia melakukan pembaharuan terhadap UU No.7 Tahun 1987 yang kemudian lahir UU No.12 Tahun 1997 tentang Hak Cipta. Dalam kenyataannya upaya pembaharuan ini masih terus bergulir, dengan diperbaharuinya ketentuan UU No.12 Tahun 1997 menjadi UU No.19 Tahun 2002 tentang Hak Cipta. UU No.19 Tahun 2002 merupakan produk paling akhir yang diberlakukan dan menjadi dasar hukum bagi pengaturan hak cipta di Indonesia. Indonesia mengakui dan memberikan penghargaan terhadap karya cipta dan mekanisme perlindungan Haknya dalam Undang-Undang Nomor 19 Tahun 2002 tentang Hak Cipta (UUHC 2002), yang dari segi substansi, terdapat beberapa ketentuan penting yang yang saling terkait dan bahkan akan dapat menjadi instrumen strategis dalam menunjang proses dan mekanisme penegakan hukum Hak Cipta. Secara khusus UUHC mengatur tentang Pendaftaran Ciptaan. (Suyud Margono, $2012: 4$ )

Selain peraturan perundang-undangan yang telah disebutkan di atas, masih ada ketentuan lain mengenai Hak Cipta di Indonesia sebelum adanya UUHC Nomor 19 Tahun 2002. Ketentuan-ketentuan itu adalah :

a. Peraturan Pemerintah Nomor 14 Tahun 1986 jo Peraturan Pemerintah Nomor 7 tahun 1989 Tentang Dewan Hak Cipta

b. Peraturan Pemerintah Nomor 1 Tahun 1989 Tentang Penerjemahan dan/atau Perbanyakkan Ciptaan untuk Kepentingan Pendidikan, Ilmu Pengetahuan, Penelitian dan Pengembangan

c. Peraturan Menteri Kehakiman Nomor M.01-HC.03.01/1987 Tentang Pendaftaran Ciptaan

d. Keputusan Menteri Kehakiman Nomor M.04.PW.03/1988 Tentang Penyidikan Hak Cipta

e. Surat Edaran Menteri Kehakiman Nomor M.01.PW.07.03/1990 Tentang Kewenanangan Menyidik Tindak Pidana Hak Cipta

Keberadaan UUHC memang diperuntukkan khusus untuk melindungi hak bagi mereka yang telah menghasilkan karya-karya yang berasal dari pengungkapan (ekspresi) intelaktualitas (intangible), dan bukannya yang bersifat kebendaan (tangible), apabila yang belum berwujud apa-apa seperti ide-ide informasi dan lain sebagainya tersebut dengan batasan waktu tertentu. (Tommy Hottua Marbun dan T. Keizeirina Devi Azwar, 2013 : 4). Pemerintah menjadikan permasalahan Hak Kekayaan Intelektual (HKI) sebagai salah satu prioritas ditunjukkan dengan adanya beberapa perjanjian internasional yang kemudian diratifikasi oleh Pemerintah Indonesia melalui Keputusan Presiden. Beberapa Keputusan Presiden tentang Pengesahan Persetujuan Timbal Balik Hak Cipta, yaitu :

a. Keputusan Presiden Nomor 17 Tahun 1988 Tentang Pengesahan Persetujuan Timbal Balik Hak Cipta Antara Pemerintah RI dengan Masyarakat Eropa

b. Keputusan Presiden Nomor 25 Tahun 1989 Tentang Pengesahan Persetujuan Timbal Balik Hak Cipta Antara Pemerintah RI dengan Amerika Serikat 
c. Keputusan Presiden Nomor 38 Tahun 1993 Tentang Pengesahan Persetujuan Timbal Balik Hak Cipta Antara Pemerintah RI dengan Australia

d. Keputusan Presiden Nomor 56 Tahun 1994 Tentang Pengesahan Persetujuan Timbal Balik Hak Cipta Antara Pemerintah RI dengan Inggris

e. Keputusan Presiden Nomor 18 Tahun 1997 Tentang Pengesahan Bern Convention

f. Keputusan Presiden Nomor 19 Tahun 1997 Tentang Pengesahan WIPO Copyright Treaty

Tumbuh berkembangnya perekonomian berdampak pada peningkatan semakin besar tingkat persaingan di dunia usaha, sehingga dimungkinkan munculnya persaingan tidak sehat, khususnya dalam dunia Hak Kekayaan Intelektual. Permasalahan-permasalahan seperti itu sangat beragam keberadaannya. Salah satu isu yang menarik adalah menyangkut hak cipta. Beberapa waktu yang lalu masyarakat Indonesia di kejutkan dengan adanya kasus Sengketa hak Cipta yang proses hukumnya terjadi di Pengadilan Negeri Karanganyar, yaitu sengketa Hak Cipta antara PT Sri Rejeki Isman (Sri Tex) Sukoharjo dengan PT. Delta Merlin Dunia Tex Karanganyar. Faktor yang menjadi perdebatan adalah bahwa kasus ini secara de facto memang ada, tetapi secara de jure kasus ini mengalami kesulitan dalam hal apakah perbuatan tersebut dapat dikategorikan sebagai pelanggaran hak cipta atau bukan. Kemudian apabila ada pelanggaran hak cipta, bagaimana penyelesaiannya secara hukum terkait dengan sistem hukum hak cipta di Indonesia.

Oleh sebab hal-hal tersebut diatas maka perlindungan terhadap hak cipta perlu terus dilakukan. Sebab saat ini banyak pembajakan Hak Cipta. Misalnya saja peniruan website, pembajakan lagu dalam format mp3, atau software-software bajakan juga mudah ditemukan diinternet, produk terkstil serta pembajakan hak cipta lainnya. Hal tersebut selain menimbulkan kerugian bagi penciptanya juga menimbulkan kerugian bagi negara atas pajak yang tidak dibayarkan. Seperti diketahui bahwa, pelanggaran hak cipta berakibat yang sangat serius karena dapat merusak struktur dan sistem economic right. Latar belakang dari pelanggaran itu pada dasarnya berkisar pada keinginan untuk mencari keuntungan finansial secara cepat dan mudah dengan mengabaikan kepentingan para pemegang hak cipta. Undang-Undang No. 6 tahun 1982 tentang Hak Cipta, kemudian Undang-Undang Nomor 7 Tahun 1987, UndangUndang No. 12 tahun 1997 dan terakhir muncul Undang-Undang No. 19 tahun 2002 tentang Hak Cipta seperti sudah dijelaskan di muka, merupakan revisi terbaru dari undang-undang sebelumnya. Dalam undang-undang itu disebutkan bahwa ciptaan-ciptaan yang dilindungi adalah ciptaan dalam bidang ilmu, sastra, seni tetapi dengan batasan tersebut tampaknya tidak mudah untuk menerapkan begitu saja pasal-pasal undang-undang hak cipta terhadap pelanggaran hak cipta di dalam dunia usaha.

Hak cipta sebagai bagian dari hak kekayaan intelektual, dalam sistem hukum Indonesia diatur dalam Undang-Undang Nomor 19 Tahun 2002 tentang Hak Cipta. Namun perlindungan hukum Hak Cipta dalam kehidupan sehari-hari, belum sepenuhnya dapat dijalankan, dapat dimungkinkan karena faktor penegak hukumnya atau masih lemahnya pengawasan dari pemerintah. Hal ini terlihat dengan semakin banyaknya sengketa Hak Cipta yang terjadi di Pengadilan Negeri, salah satunya adalah di Pengadilan Negeri Karanganyar.

Hakim dalam memutus sebuah perkara dan mempertimbangkan layak tidaknya seseorang dijatuhi pidana seorang hakim didasarkan oleh keyakinan hakim dan tidak hanya berdasarkan bukti - bukti yang ada. Secara normatif, pengadilan adalah tempat untuk mendapatkan keadilan. Hal itu tersandang dari namanya "pengadilan" dan dari irah-irah putusan Hakim 
yang menjadi gawangnya. Menurut irah-irah itu, dalam menyelesaikan perkara Hakim tidak bekerja “demi hukum" atau "demi undang-undang”, melainkan "Demi Keadilan Berdasarkan Ketuhanan Yang Maha Esa". Frase "Berdasarkan Ketuhanan Yang Maha Esa" menjadi simbol bahwa Hakim bekerja mewakili Tuhan Yang Maha Esa. Frase itu juga menjadi jaminan bahwa Hakim dalam menyelesaikan perkara akan bekerja secara jujur, bersih, dan adil karena ia mengatas namakan Tuhan. Sebab jika tidak demikian, maka Hakim yang tidak berlaku jujur, bersih, dan adil, kelak di "pengadilan terakhir" ia harus mempertanggungjawabkan perbuatan dan perilakunya di hadapan Tuhan Yang Maha Adil.

Putusan pengadilan adalah penyataan hakim yang diucapkan pada sidang pengadilan yang terbuka untuk umum untuk menyelesaikan atau mengakhiri suatu perkara. Putusan dapat dijatuhkan setelah pemeriksaan perkara selesai dan oleh pihak-pihak yang berperkara sudah tidak ada lagi yang ingin dikemukakan. Putusan pengadilan merupakan suatu yang sangat diharapkan oleh pihak-pihak yang berperkara, sebab dengan putusan pengadilan tersebut pihak-pihak yang berperkara mengharapkan adanya kepastian hukum dalam perkara yang mereka hadapi.

Untuk memberikan putusan pengadilan yang benar-benar menciptakan kepastian hukum dan mencerminkan keadilan, hakim yang melaksanakan peradilan harus benarbenar mengetahui duduk perkara yang sebenarnya dan peraturan hukum yang mengaturnya untuk diterapkan, baik peraturan hukum yang tertulis dalam peraturan perundang-undangan maupun hukum yang tidak tertulis dalam hukum adat. Namun kenyataannya tidak selalu sejalan dengan gagasan normatifnya. Tidak selamanya Hakim memiliki kesadaran di dalam hatinya bahwa kelak ia akan mempertanggungjawabkan hasil pekerjaannya di hadapan Tuhan Yang Maha Esa. Oleh karenanya tidak jarang terdapat putusan-putusan Hakim yang tidak mencerminkan rasa keadilan. Tidak semua Hakim memiliki rasa takut bahwa kelak ia akan bertanggung jawab kepada Tuhan Yang Maha Esa tentang apa yang telah diputuskannya. Memang sulit untuk mengukur secara matematis, putusan Hakim yang bagaimana yang memenuhi rasa keadilan itu. Akan tetapi tentu saja ada indikator yang dapat digunakan untuk melihat dan merasakan bahwa suatu putusan telah memenuhi rasa keadilan atau tidak. Indikator itu antara lain dapat ditemukan di dalam "pertimbangan hukum" yang digunakan Hakim.

Pertimbangan hukum merupakan dasar argumentasi Hakim dalam memutuskan suatu perkara. Jika argumen hukum itu tidak benar dan tidak sepantasnya (proper), maka orang kemudian dapat menilai bahwa putusan itu tidak benar dan tidak adil. Pertimbangan hukum yang tidak benar dapat terjadi karena berbagai kemungkinan (Kuncoro Surbakti, 1999: 22): 1. Hakim tidak mempunyai cukup pengetahuan hukum tentang masalah yang sedang ditangani. Namun secara normatif seharusnya hal ini tidak boleh terjadi, karena Hakim dapat memerintahkan setiap pihak untuk menyediakan ahli yang akan memberikan keterangan dan menjelaskan pokok persoalannya di dalam persidangan.

2. Hakim sengaja menggunakan dalil hukum yang tidak benar atau tidak semestinya karena adanya faktor lain seperti adanya tekanan pihak-pihak tertentu, suap, dan faktor-faktor lain yang mempengaruhi independensi Hakim yang bersangkutan.

3. Hakim tidak memiliki cukup waktu untuk menuliskan semua argumen hukum yang baik disebabkan karena terlalu banyaknya perkara yang harus diselesaikan dalam kurun waktu yang relatif singkat. 
4. Hakim malas untuk meningkatkan pengetahuan dan wawasannya, sehingga berpengaruh terhadap kualitas putusan yang dibuatnya. Faktor ini merupakan faktor yang pengaruhnya tidak langsung, namun cukup menentukan kualitas putusan.

Secara ideal, semua kemungkinan yang disebutkan di atas tidak boleh terjadi dalam lembaga peradilan. Jika hal itu terjadi, maka bukan tidak mungkin lembaga peradilan yang seharusnya menjadi gerbang keadilan, justru menjadi tempat terjadinya ketidakadilan. Tidak terkecuali Mahkamah Agung sebagai lembaga pengadilan tertinggi di negeri ini. Hakimhakim Agung yang seharusnya menjadi penjaga gawang keadilan terakhir, boleh jadi justru menjadi pihak yang menciptakan ketidakadilan.

Seharusnya fakta persidangan merupakan dasar/bahan untuk menyusun pertimbangan majelis hakim sebelum majelis hakim membuat analisa hukum yang kemudian digunakan oleh hakim tersebut untuk menilai apakah terdakwa dapat dipersalahkan atas suatu peristiwa yang terungkap di persidangan untuk memperoleh keyakinan apakah terdakwa patut dipersalahkan, patut dihukum atas perbuatannya sebagaimana yang terungkap dipersidangan. singkatnya, suatu putusan harus didasarkan pada fakta persidangan dan dibarengi dengan putusan yang mencerminkan rasa keadilan. Dari paparan di atas yang menjadi pokok kajian adalah apakah Putusan Hakim Pengadilan Negeri Karanganyar dalam memutus perkara No.172/Pid.B/2011/ PN.Kray dalam kasus Hak Cipta antara PT. Sri Rejeki Isman dengan PT. Delta Merlin Dunia Texstile sudah menciptakan kepastian hukum.

\section{B. Metode Penelitian}

Penelitian ini merupakan penelitian normatif dengan mempergunakan Jenis data Sekunder. Sumber data yang dipergunakan adalah Sumber data sekunder terdiri dari bahan Hukum Primer, bahan Hukum Sekunder serta bahan Hukum Tersier. Pencarian data dengan Studi Pustaka. Analisis data menggunakan metode analisa logika deduktif dengan pendekatan kualitatif.

\section{Hasil Penelitian dan Pembahasan}

Putusan Hakim Pengadilan Negeri Karanganyar No.172/Pid.B/2011/PN.Kray dalam kasu Hak Cipta antara PT. Sri Rejeki Isman dengan PT. Delta Merlin Dunia Texstile Putusan yang dijatuhkan dapaat dilihat bahwa :

- Menyatakan terdakwa JAU TAU KWAN bin JAU JU MING tidak terbukti secara sah dan meyakinkan bersalah melakukan tindak pidana sebagaimana didakwakan kepadanya baik dalam dakwaan kesatu maupun dakwaan kedua;

- Membebaskan terdakwa tersebut oleh karena itu dari segala dakwaan Jaksa Penuntut Umum

- Memulihkan hak terdakwa dalam kemampuan, kedudukan dan harkat serta martabatnya

- Menetapkan barang bukti berupa:

- 1 (satu) rol kain grey warna putih strip kuning pada tepi kain produksi PT SRITEX Sukoharjo 
Dikembalikan kepada PT SRITEX

- 1 (satu) rol kain grey warna putih strip kuning pada tepi kain produksi PT DUNIATEX Karanganyar

- 2 (dua) lembar sampel potongan kain grey dengan kode benang kuning pada bagian pinggir kain

- 4 (empat) lembar faktur pengiriman barang dengan jenis barang R8464100 kepada ratu modern Jakarta dengan nomor faktur : 004291 tanggal 18-6-2011, 003638 tanggal 18-5-2011, 004176 tanggal 13-6-2011, 0037703 tanggal 21-5-2011

- 5 (lima) lembar surat jalan pengiriman barang dengan jenis barang R8464100 kepada Ratu modern jakarta nomor surat jalan : 004291 tanggal 18-6-2011, 003638 tanggal 18-5-2011, 004176 tanggal 13-6-2011, 0037703 tanggal 21-5-2011

- 3 (tiga) lembar surat tanda terima barang dari PT Jala Anugerah Sejati jala expres nomor 05986, 06147, 05992

- 9 (sembilan) lembar packing list jenis barang R 8464100 kepada ratu modern dengan nomor 052105, 052106, 052107, 052231, 052232, 052233, 050847, 050848, 050849

- 1 (satu) buku pengiriman barang motif batik warna kuning-hijau-putih

- 1 (satu) bendel surat jalan PT Delta Merlin Dunia Textile II nomor 014201-014250

- 15 (limabelas) unit mesin tenun

- 15 (limabelas) unit stand cucuk

- 1 (satu) set mesin SIZING jenis TAYA Type 1G-E201MFG no. 0102 nomor 1 (yang berdasarkan penetapan hakim dipinjamkan kepada Prof. Dr. OC. Kaligis, Sh MH)

- 1 (satu) lembar nota no 000234 tanggal 30/4 atas pembelian benang warna kuning /B.yml 500 banyaknya 2 satuan gros harga@ Rp. 116.500 (seratus enam belas ribu lima ratus rupiah)

- 1 (satu) lembar kontrak penjualan nomor 126/DMDT II/PG/IV/2011 tanggal 26 April 2011 DELTA MERLIN DUNIA TEKSTIL, penjualan kain grey jenis barang R'30 S x R' 30 S 8464100 jumlah 150.000 yard, harga Rp. 6.500 (enam ribu lima ratus rupiah) total Rp. 975.000.000 (sembilan ratus tujuh puluh juta rupiah)

- Catatan tangan sdri THERESIA ARIS PUJIWATI) admin marketing PT Delta Merlin Dunia Tekstil) tentang data pengiriman kain grey ke Ratu Modern bedasarkan kontrak penjualan nomor : 126/DMDT II/PG/IV/2011 tanggal 26 April 2011

- 8 (delapan) lembar nota pembelian dari PT SRITEX no. 019325 tanggal 14 April 2010, no 020876 tanggal 05 November 2010, no. 020826 tanggal 01 November 2010, no. 017466 tanggal 25 Februari 2011, no. 022420 tanggal 10 Mei 2011, no, 022491 tanggal 21 mei 2011

- 1 (satu) unit CPU merek ASUS procesor Intel Pentium (r) 4 CPU $3.00 \mathrm{GHz}$ system Type 32-bit operating system dengan produk ID 89572-OEM-7300981-68486

Dikembalikan kepada PT DUNIATEX

- 8 (delapan) lembar confirmastion of sale / kontrak penjualan PT SRI REJEKI ISMAN atas penjualan kain Grey R 29/ kain grey seni terapan KODE BENANG KUNING dengan PT Kraton Mas yaitu No : 09351/SR/IX/2010, tanggal 30 Agustus 2010, No.09352/SR/IX/2010 tanggal 22 September 2010. No 08347/SR/VIII/2010 tanggal 05 Agustus 2010, No, 07346/SR/VII/2010 tanggal 21 Juli 2010, No. 06344/ 
SR/VI/2010 tanggal 14 Juni 2010, No. 05343/SR/V/2010 tanggal 03 Mei 2010, No. 03334/SR/III/2010 tanggal 03 Maret 2010, No. 001327/SR/XII/2010 tanggal 08 Januari 2010.

- 3 (tiga) lembar nota pembelian kain grey R29/ kain grey seni terapan kode benang kuning yaitu no.15257 tanggal 19 Oktober 2008, No. 16133 tanggal 14 Februari 2009, No. 016260 tanggal 03 maret 2009

Dikembalikan kapada Sdr. WIRYANTO SUHADI alias AHWAT

- 2 (dua) lembar nota konsinyasi SRITEX no. 021700 tanggal 08 Februari 2011 dan no. 021647 tanggal 01 Februari 2011

- 1 (satu ) lembar slip pemindahan dana antar rekening BCA dari no rekening 369-107388-1 nama LIE LAY HOK kepada penerima rekening 015-121-745-1 atas nama PT DELTA MERLIN DUNIA TEKSTIL sebesar Rp. 75.236 .250 (tujuh puluh lima juta dua ratus tiga puluh enam ribu dua ratus lima puluh rupiah) tanggal 16-8-2011

- 1 (satu) lembar slip pemintahan dana antara rekening BCA dari no rekening 369107-388-1 nama LIE LAY HOK kepada penerima rekening 015-121-745-1 atas nama PT DELTA MERLIN DUNIA TEKSTIL sebesar Rp.112.552.500 (seratus dua belas juta lima ratus lima puluh dua ribu lima ratus rupiah ) tanggal 16-8-2011

- 1 (satu) lembar slip setoran bank BCA tanggal 22-7-2011 ke no rekening 015-121745-1 atas nama PT DELTA MERLIN DUNIA TEKSTIL sebesar Rp. 195.019.500 (seratus sembilan puluh lima juta sembilan belas ribu lima ratus rupiah)

Dikembalikan kepada Sdr LIE LAY HOK alias HERMAN

- 1 (satu) lembar surat jalan dengan menggunakan kop PT Dunia Setia Sandang Asli Tekstil alamat Jl. H Fachrudin 36, Proyek Tanah Abang Bukit Blok A-24 Jakarta Pusat no 13604 tanggal 27-7-2011 kepada batik Gajah mada, jenis barang rayon 8464100 30S, warna greige, yard 150 meter

- 1 (satu) lembar nota penjualan menggunakan kop PT Dunia Setia Sandang Asli Tekstil alamat J1. H Fachrudin 36, Proyek Tanah Abang Bukit Blok A-24 Jakarta Pusat tanggal 27-7-2011 kepada GAJAH MADA BATIK Jl Karet Pedurenan GG Sidik Jakarta kode sales DNT. Faktur jual no 1107-36887-13604, nama barang RAYON30S8464100CM SHUTTLE/GREIGE, banyaknya 150 meter, harga 5.200, jumlah 780.000 (tujuh ratus delapan puluh ribu rupiah)

Dikembalikan keapda Sdr Gandi untuk diteruskan kepada pemilik Batik Gajah mada

- Membebankan biaya perkara ini kepada Negara

Demikian diputuskan berdasarkan musyawarah Majelis Hakim pada hari Senin tanggal 12 maret 2012 oleh kami : DJOKO INDIARTO, SH Ketua Pengadilan Negeri Karanganyar selaku Hakim Ketua Sidang serta T.BENNY EKO SUPRIYADI SH dan SYAHRU RIZAL SH, MH masing-masing selaku Hakim-Hakim Anggota, Putusan mana diucapkan pada hari Kamis tanggal 22 Maret 2012 dalam sidang yang terbuka untuk umum oleh Majelis Hakim tersebut dengan didampingi oleh YULIANA SRI SUGIARTI, Panitera Pengganti pada Pengadilan Negeri tersebut dan dihadiri oleh Jaksa Penuntut Umum pada Kejaksaan Negeri Karanganyar serta dihadapan terdakwa dan para penasihat hukum terdakwa.

Dari paparan di atas dapat dijelaskan bahwa Hakim sebagai penegak hukum dan keadilan wajib menggali, mengikuti dan memahami nilai-nilai hukum yang hidup dalam masyarakat dan dalam mempertimbangkan berat ringannya pidana, hakim wajib memperhatikan pula 
sifat-sifat yang baik dan jahat dari tertuduh. Semua masyarakat yang masih mengenal hukum tidak tertulis, serta berada dalam masa pergelokan dan peralihan, hakim merupakan perumus dan penggali dari nilai-nilai hukum yang hidup di kalangan rakyat. Untuk itu ia harus terjun ke tengah-tengah masyarakat untuk mengenal, merasakan dan mampu menyelami perasaan hukum dan rasa keadilan yang hidup dalam masyarakat. Dengan demikian hakim dapat memberikan putusan yang sesuai dengan hukum dan rasa keadilan masyarakat. Sifat-sifat yang jahat maupun yang baik dari tertuduh wajib diperhatikan hakim dalam mempertimbangkan pidana yang akan dijatuhkan. Keadaan-keadaan pribadi seseorang perlu diperhitungkan untuk memberikan pidana yang setimpal dan seadil-adilnya. Paham yang menyatakan bahwa hakim tidak lain dari pada sebagai pengucap undang-undang atau corongnya undang-undang belaka (La bouchequi prononce les paroles de loi) telah ditinggalkan, atau tidak dianut lagi dan sudah lama ditinggalkan.

Selain itu hakim menyesuaikan (waarderen) undang-undang dengan hal-hal yang konkrit yang terjadi di masyarakat dan hakim dapat menambah (aanvullen) undang-undang apabila perlu. Hakim harus menyesuaikan undang-undang dengan hal yang konkrit, karena undangundang tidak meliputi segala kejadian yang timbul dalam masyarakat. Bukankah pembuat undang-undang hanya menetapkan suatu petunjuk hidup yang umum saja? Pertimbangan mengenai hal-hal yang konkrit, yaitu menyesuaikan undang-undang khususnya berkaitan dengan hak cipta dengan hal-hal yang konrit diserahkan kepada hakim.

Keputusan hakim dapat memuat suatu hukum dalam suasana "werkelijkheid" yang menyimpang dari hukum dalam suasana "positiviteit". Hakim menambah undang-undang karena pembuat undang-undang senantiasa tertinggal pada kejadian-kejadian yang baru yang timbul di masyarakat. Undang-undang itu merupakan suatu "momentopname" saja, yaitu suatu "momentopname" dari keadaan di waktu pembuatannya. Berdasarkan dua kenyataan tadi, maka dapat dikatakan bahwa hakim pun turut serta menentukan mana yang merupakan hukum dan mana yang tidak. Kemandirian hakim dalam menemukan dan pembentukan hukum itu, serta dapat menentukan mana yang merupakan hukum dan mana yang tidak atau dalam mengisi ruangan yang kosong dalam undang-undang, adalah tidak bertentangan dengan undang-undang, karena keputusan hakim yang demikian itu hanya berlaku bagi para pihak yang berperkara saja dan tidak berlaku sebagai peraturan umum. Namun keputusan hakim yang didasarkan oleh hukum yang ditemukannya itu, dalam keadaan dan waktu tertentu, dapat diikuti oleh hakim-hakim yang lain dalam hal perkara yang sama dan akhirnya menjadi suatu yurisprudensi yang tetap dan sekaligus menjadi sumber hukum yang formil. Hakim wajib mengikuti keputusan hakim yang kedudukannya menurut hirarki pengadilan lebih tinggi, wajib mengikuti keputusan hakim yang lain yang kedudukannya sederajat, tetapi telah lebih dahulu membuat penyelesaian suatu perkara semacam, bahkan wajib mengikuti keputusan sendiri yang dibuatnya lebih dahulu dalam perkara semacam (stare desicis). Hukum yang berasal dari pengadilan preseden disebut "judge made law" atau "judiciary law". Terutama di negeri Inggris sering "judge made law" itu dianggap lebih penting dari pada "Statute law" (hukum yang ada di dalam peraturan perundang-undangan). Pentingnya "judge made law" itu diperbesar oleh Gray dalam rumusannya "All the law is judge made law".

Fungsi hakim yang bebas untuk mencari dan merumuskan nilai hukum adat dalam masyarakat, diharapkan dapat memfungsikan hukum untuk merekayasa masyarakat dalam seluruh aspek kehidupan dengan memenuhi rasa keadilan, kegunaan dan kepastian hukum 
secara serasi, seimbang dan selaras. Dewasa ini di Indonesia telah berkembang faham untuk mengfungsikan hukum sebagai rekayasa sosial (law as a tool of social engineering) terutama dalam bidang hukum privat adat menjadi hukum privat nasional.

Berbekalkan konsep dan rancangan kebijakan seperti itu, tak pelak para pendukung hukum adat tak dapat bertindak lain selain mengandalkan kemampuan para hakim untuk mengembangkan pendayagunaan hukum dalam masyarakat, atas dasar prinsip-prinsip kontigensi yang harus benar-benar kreatif. Sekalipun dalam era orde baru badan-badan kehakiman diidealkan akan menjadi hakim yang bebas dan pembagian kekuasaan dalam pemerintah akan dihormati dengan penuh komitmen, akan tetapi harapan-harapan kepada badan-badan ini sebagai badan yang mandiri dan kreatif untuk merintis pembaharuan hukumlewat pengartikulasian hukum dan moral rakyat agaknya terlampau berkelebihan.

Salah satu aspek dalam kehidupan hukum adalah kepastian, artinya, hukum berkehendak untuk menciptakan kepastian dalam hubungan antar orang dalam masyarakat. Salah satu yang berhubungan erat dengan masalah kepastian tersebut adalah masalah dari mana hukum itu berasal. Kepastian mengenai asal atau sumber hukum menjadi penting sejak hukum menjadi lembaga semakin formal.

Kemampuan para hakim kita agaknya dihadapkan dengan suatu dilema, antara harapan dan kenyataan, terlebih lagi dalam era globalisasi ini. Kebutuhan hukum dalam masyarakat dengan cepat berkembang, sehingga para hakim "diharapkan" dapat menyesuaikan hukum dengan peristiwa yang konkrit dan mengambil keputusan berdasarkan hukum yang ditemukannya sendiri dan akhirnya dapat menjadi yurisrpudensi yang tetap dan berwibawa. Hakim dalam menyesuaikan peraturan perundang-undangan dengan suasana konkrit untuk menegakkan keadilan dan kebenaran serta kepastian hukum (rechts zekerheid), harus dapat memberi makna dari isi ketentuan undang-undang serta mencari kejelasan dengan melakukan penafsiran yang disesuaikan dengan kenyataan, sehingga undang-undang itu dapat berlaku konkrit jika dihadapkan dengan peristiwanya.

Dari analisis tersebut di atas, sebenarnya hakim Pengadilan negeri karanganyar, Sesuai dengan keyakinannya, telah melakukan sebuah tindakan yang abenar, yaitu Putusan Hakim dalam perkara No.172/Pid.B/2011/PN.Kray dalam sengketa Hak Cipta antara PT. Sri Rejeki Isman dengan PT. Delta Merlin Dunia Texstile

\section{Simpulan}

Adapun kesimpulan dalam penulisan ini adalah sebagai berikut.

Keputusan Hakim Pengadilan Negeri Karanganyar dalam memutus perkara No.172/ Pid.B/2011/PN.Kray dalam kasus Hak Cipta antara PT. Sri Rejeki Isman dengan PT. Delta Merlin Dunia Texstile sudah menciptakan kepastian hukum. Putusan yang dijatuhkan oleh hakim pengadilan negeri Karanganya No.172/Pid.B/2011/PN.Kray dalam kasus Hak Cipta antara PT. Sri Rejeki Isman dengan PT. Delta Merlin Dunia Texstile memberikan kepastian hukum bagi para pihak yang bersengketa. Putusan Hakim bersifat incrach atau memiliki kekuatan hukum tetap. 


\section{E. Saran}

Berdasarkan kesimpulan disarankan sebagai berikut.

1. Bagi Pemerintah

Perlu diadakan sosialisasi kepada masyarakat terkait Undang-undang hak cipta, agar masyarakat dapat memahami dan mengetahui perihal hak cipta, merk dan sejenisnya,

2. Bagi Hakim

Penting rasa keadilan dan hati nurani yang adil yang perlu ditanamkan pada setiap insan hakim. Jangan takut memutus sebuah perkara meskipun telah mempunyai polisi hakim (KY). Kalau menurut keyakinan seorang hakim dan menurut rasa keadilan hati nurani dan hukumnya telah sesuai dengan Demi Keadilan Berdasarkan Ke Tuhanan Yang Maha Esa. Oleh karenanya Aparat hukum terutama aparat Pengadilan khususnya hakim harus mengetahui bahwa putusan Pengadilan merupakan suatu yang sangat diinginkan atau dinanti-nanti oleh pihak-pihak yang berperkara untuk menyelesaikan sengketa mereka dengan sebaik-baiknya sebab dengan putusan tersebut pihak-pihak yang bersengketa mengharapkan adanya kepastian hukum-hukum keadilan dalam perkara yang mereka hadapi dan mereka betul-betul merasa mendapatkan keadilan yang diharapkan para pencari keadilan tersebut. selain itu diharapkan kepada para penegak hukum bahwa di dalam proses pembentukan hukum dan proses penemuan hukum agar dapat mengkaji dan menggali nilai-nilai hukum yang hidup di dalam masyarakat, agar dapat tercapai tujuan hukum.

\section{F. Daftar Pustaka}

\section{Buku-buku}

Abdulkadir Muhammad. 2001. Kajian Hukum Ekonomi Hak Atas Kekayaan Intelektual. Bandung: Citra Aditya bandung.

Abdul Wahab Solichin.1991, Teori Implementasi, Jakarta, Raja Grafindo

Andi Ayyub Saleh, 2001, Tamasya Perenungan Hukum dalam "Law in Book and Law in Actio Adami Chazawi.. Pelajaran Hukum Pidana. Jakarta : PT. Raja Grafindo Persada

Bambang Purnomo. 1983. Asas-asas Hukum Pidana, Yogjakarta: Ghalia Indonesia

Hendra Tanu Atmadja, 2003, Hukum Hak Cipta. Bandung : Alumni

Faisal, 2010. Menerobos Positivisme Hukum, Yogyakarta, Rangkang Education, HB. Sutopo. 2002. Metodologi Penelitian Kualitatif. Surakarta : UNS Press

J.E. Jonkers, 1987. Hukum Pidana Hindia Belanda. Tim Penerjemah Bina Aksara. Jakarta: PT Bina Aksara.

H.OK. S Daidin, 2004, Aspek Hukum Hak Kekayaan Intelektual Suatu Pengantar, Bandung, Alummi

Kuncoro Surbakti, 1999, Aspek-aspek Putusan hakim, Bandung, Alumni, 
Leden Marpaung, 1992. Proses Penanganan Perkara Pidana. Jakarta : Sinar Grafika .1995. Tindak Pidana Terhadap Hak atas Kekayaan Intelektual. Sinar Grafika : Jakarta.

PAF. Lamintang. 1997. Dasar-Dasar Hukum Pidana Indonesia. Bandung : PT. Citra Aditya Bhakti Peter Mahmud Marzuki, 2005, Penelitian Hukum, Jakarta. Kencana Prenada Media

Rachmadi Usman. 2003. Hukum Hak Atas Kekayaan Intelektual. Bandung : Alumni.

Satjipto Rahardjo, 2000, Ilmu Hukum. Bandung, PT. Citra Aditya Bhakti,

Sabian Usman,2009, Dasar-Dasar Sosiologi Hukum, Yogyakarta, Pustaka Belajar

Setiono,2002, Pemahaman terhadap Metode Penelitian Hukum, (Diktad). Surakarta: Program Studi Ilmu Hukum Pascasarjana UNS

Soejono Soekarno dan Sri Mamdji,1985, Penelitian Hukum Normatif, Jakarta, CV. Rajawali

Undang - Undang

Undang-Undang Dasar Negara Republik Indonesia Tahun 1945

Kitab Undang-Undang Hukum Pidana

Undang-Undang Nomor 8 Tahun 1981 tentang Hukum Acara Pidana

Undang-Undang No.19 Tahun 2002 tentang Hak Cipta tentang Hak Cipta

Undang-Undang Nomor 48 Tahun 2009 tentang Kekuasan Kehakiman

\section{Jurnal :}

Suyud Margono, 2012, Hak Cipta, Kontradiksi Kaedah Pendaftaran Ciptaan dengan Asas Kepemilikan Publikasi Pertama Kali, Jurnal Rechts Vinding, Media Pembinaan Hukum Nasional, Volume 1 No. 2, Agustus 2012

Tommy Hottua Marbun dan T. Keizeirina Devi Azwar,2013, Perlindungan Hukum Hak Cipta terhadap Karya Cipta lagu dan Musik dalam bentuk ringtone pada telepon seluler, Transparency, Jurnal Hukum Ekonomi, Feb-Mei 2013, Volume I No. 1 